\title{
Clinical and Paraclinical Characteristics of COVID-19 patients: A systematic review and meta-analysis
}

Keyvan Heydari ${ }^{1,2}$, Sahar Rismantab ${ }^{3 *}$, Amir Shamshirian ${ }^{4,2}$, Parisa Lotfi ${ }^{1}$, Nima Shadmehri ${ }^{5}$, Pouya Houshmand $^{6}$, Mohammad Zahedi ${ }^{4}$, Danial Shamshirian ${ }^{7}$, Sahar Bathaeian $^{8}$, Reza Alizadeh-Navaei ${ }^{2 *}$

1. Student Research Committee, School of Medicine, Mazandaran University of Medical Sciences, Sari, Iran.

2. Gastrointestinal Cancer Research Center, Mazandaran University of Medical Sciences, Sari, Iran.

3. Ramsar Campus, Mazandaran University of Medical Sciences, Ramsar, Iran.

4. Department of Medical Laboratory Sciences, Student Research Committee, School of Allied Medical Science, Mazandaran University of Medical Sciences, Sari, Iran.

5. Science Department, University of Tehran, Tehran, Iran.

6. Faculty of Veterinary Medicine, University of Tehran, Tehran, Iran.

7. Chronic Respiratory Diseases Research Center, National Research Institute of Tuberculosis and Lung Diseases (NRITLD), Shahid Beheshti University of Medical Sciences, Tehran, Iran.

8. Influenza Research Lab, Department of Virology, Pasteur Institute of Iran, Tehran, Iran. 
Introduction: Recently, a new strain of coronaviruses, which originated from Wuhan City, Hubei Province, China has been identified. According to the high prevalence of new coronavirus, further investigation on the clinical and paraclinical features of this disease seems essential. Hence, we carried out this systematic review and meta-analysis to figure out the unknown features.

Methods: This study was performed using databases of Web of Science, Scopus and PubMed. We considered English cross-sectional and case-series papers which reported clinical, radiological, and laboratory characteristics of patients with COVID-19. We used STATA v.11 and random effect model for data analysis.

Results: In the present meta-analysis, 32 papers including 49504 COVID-19 patients were studied. The most common clinical symptoms were fever (84\%), cough (65\%) and fatigue (42\%), respectively. The most common radiological and paraclinical features were bilateral pneumonia (61\%), ground-glass opacity (50\%), thrombocytopenia (36\%) and lymphocytopenia (34\%). The study also showed that the frequency of comorbidities and early symptoms was higher in critically severe patients. Moreover, we found the overall mortality rate of three percent.

Conclusion: According to that there are many cases without Computed Tomography Scan findings or clear clinical symptoms, it is recommended to use other confirming methods such RNA sequencing in order to identification of suspicious undiagnosed patients. Moreover, while there is no access to clinical and paraclinical facilities in in public places such as airports and border crossings, it is recommended to consider factors such as fever, cough, sputum and fatigue.

Keywords: COVID-19, SARS-CoV-2, Coronaviridae, Clinical Manifestation 
medRxiv preprint doi: https://doi.org/10.1101/2020.03.26.20044057; this version posted March 30, 2020. The copyright holder for this preprint (which was not certified by peer review) is the author/funder, who has granted medRxiv a license to display the preprint in perpetuity.

All rights reserved. No reuse allowed without permission.

\section{Introduction}

Coronavirus is a type of enveloped RNA virus with size of 60 to 140 nanometers in diameter. They have spike-like projections with a crown-like appearance under the electron microscope (1). This family of viruses, which can be divided into four type of alpha, beta, delta, and gamma, can infect multiple types of different species. For instance, they have been isolated from humans (alpha and beta), bats, Canidae, and Felidae $(2,3)$. Although the coronavirus family is mainly responsible for human mild respiratory diseases such as common cold, in some cases, they can cause serious illnesses (3). Middle east respiratory syndrome (MERS) and severe acute respiratory syndrome (SARS) are among epidemic diseases caused by coronaviruses in recent decades (4).

Recently, a novel strain of coronaviruses, which originated from Wuhan City, Hubei Province, China, has been identified (1). This strain (SARS-CoV-2) has been discovered in 2019 and characterized as a pandemic disease in March 2020 (5). According to World Health Organization (WHO), up to 17 March 2020, over 188,000 confirmed cases of COVID-19 had been reported throughout the world with the mortality rate of $3.4 \%(6)$.

In a study, Sun et al. assessed the incidence of fever, cough, myalgia, fatigue and ARDS in patients with CoVID-19 (7). Given the increasing prevalence of the disease, further investigation of the clinical and paraclinical features of this disease seems necessary. In this regard, we conducted this systematic and meta-analysis review. In this study, we investigated the risk of incidence of different type of clinical finding and comorbidities in severe and non-severe patients. 


\section{Material and Methods}

\section{Source information}

This systematic review and meta-analysis has been carried out on cross-sectional and case-series studies. We searched databases of Web of Science, Scopus, and PubMed without any time limitation for publications up to March 13, 2020. As manual search, the list of imported references, list of related reviews, and the results of Google Scholar have been investigated.

\section{Search strategy}

All processes of searching, screening and reporting were done according to Preferred Reporting Items for Systematic Reviews and Meta-Analyses (PRISMA) guideline. We used following keywords in our systematic search in order to find English papers: "2019 novel coronavirus infection", COVID19, “coronavirus disease 2019”, “coronavirus disease-19”, “2019-nCoV disease", "2019 novel coronavirus disease", and "2019-nCoV infection."; all in title/abstract field.

\section{Eligibility Criteria}

We considered following criteria for study selection:

- The study should have an observatory approach investigated COVID-19 patients.

- Studies on a particular group of people (e.g. pregnant women) has been excluded.

- Studies included with desired variables such as symptoms, comorbidity, laboratory findings, etc.

- Studies should be in English. English abstracts of other language studies were investigated for eligible data. 
- All the case report and animal studies were excluded.

\section{Study Selection}

Duplicated papers were deleted using EndNote software. Two researchers screened the remaining papers according to the criteria, separately. In case of disagreement between the two investigators, a third person was making the final decision.

\section{Quality assessment}

For the quality assessment, a modified version of Newcastle-Ottawa Quality Assessment (NOS) have been used. The investigated papers categorized into two categories. The studies with a score of 1 or 2 as poor quality, and studies with a score of 3 to 5 as high quality.

\section{Data Extraction}

Data such as authors information, publication year, sample size, average/median age, death rate, hospitalization status, early symptoms, laboratory findings, radiological findings and underlying diseases of patients have been extracted and recorded.

\section{Statistical Analysis}

Statistical analysis was performed using STATA v.11 software. The heterogeneity of studies has been investigated using I-square $\left(I^{2}\right)$ test. Based on the results, for $I^{2}$ more than $50 \%$, we used a random-effects model to pool the results. Moreover, to study the heterogeneity of the added study, subgroup analysis in severe and non-severe patients have been done. 


\section{Results}

\section{Study Selection Process}

The search in databases yields 351 results. After excluding duplicated papers, 364 results were admitted to the screening step. Then, 65 papers have been selected for full-text analysis. Finally, 19 studies were entered into the meta-analysis. Additionally, 13 studies obtained from manual search were included in the meta-analysis. The PRISMA flow diagram for the study selection process presented in Figure 1.

\section{Study Characteristics}

Out of selected papers, a total of 49504 patients infected with CoVID-19 with age ranged between 40 to 58 years old were included in our investigation. All of the papers were conducted in China and only one study was a collaboration between China and South Korea. Characteristics of studies entered into meta-analysis are presented in Table 1.

\section{Quality Assessment}

According to quality assessment using NOS tool, all of the studies categorized as high quality. The quality assessment graph is presented in Fig. 2 and Supplementary Fig. 1.

\section{Characteristics of Patients}

Regarding hospitalization, our findings showed that $69 \%$ of the patients need to be hospitalized. About $26 \%$ of patients were discharged after receiving outpatient treatment and only $3 \%$ of patients have been expired (Fig. 3). 
medRxiv preprint doi: https://doi.org/10.1101/2020.03.26.20044057; this version posted March 30, 2020. The copyright holder for this preprint (which was not certified by peer review) is the author/funder, who has granted medRxiv a license to display the preprint in perpetuity.

All rights reserved. No reuse allowed without permission.

\section{Clinical Findings}

Patients with COVID-19 referred to the hospital with variety symptoms. Fever, cough, and sour throat are among the most common symptoms of the patients, which were reported respectively in 22, 20, and 7 studies. Meta-analysis findings are as follows respectively: $84 \%$ (95\% CI, 79-88), 65\% (95\% CI, 59-71), and 14\% (95\% CI 8-19) (Fig. 4 and 5).

Headache, myalgia, diarrhea, and fatigue were reported in 14, 17, 16, and 13 studies with the risk of $13 \%$ (95\% CI, 8-19), 24\% (95\% CI 19-29), 9\% (95\% CI, 5-12), and 42\% (95\% CI, 34-49) (Fig. 5 and Supplementary File). Anorexia, Chills, Shortness of breath, dyspnea, chest pain, confusion, and nausea/vomiting were reported in respectively 5, 5, 6, 5, 7, 2, and 9 studies. Overall prevalence of these symptoms was $24 \%$ (95\% CI, 13-34), $19 \%$ (95\% CI, 11-27), $27 \%$ (95\% CI, 12-42), 31\% (95\% CI, 14-48), 6\% (95\% CI, 2-9), 1\% (95\% CI, 0-2) and 6\% (95\% CI, 3-8) (Supplementary File and Table 2).

In addition, sneezing, nasal congestion, rhinorrhea, hemoptysis, and expectoration were reported in $3,4,7,3$, and 4 studies, respectively. Pooling results were 26\% (95\% CI, 14-39), 24\% (95\% CI, 1-48), 4\% (95\% CI 1-6), 2\% (95\% CI, 0-3), and 39\% (95\% CI, 27-51) (Supplementary File and Table 2).

Abdominal pain, pharyngula, dizziness, and sputum production have been reported in 2, 5, 4, 8 studies, respectively. Meta-analysis findings were 4\% (95\%CI 2 - 5), 12\% (95\%CI 5 - 19), 8\% (95\%CI 6 - 10), and 27\% (95\%CI 20 - 35) (Supplementary File and Table 2).

\section{Laboratory Findings}


medRxiv preprint doi: https://doi.org/10.1101/2020.03.26.20044057; this version posted March 30, 2020. The copyright holder for this preprint (which was not certified by peer review) is the author/funder, who has granted medRxiv a license to display the preprint in perpetuity.

All rights reserved. No reuse allowed without permission.

Many studies have investigated the laboratory findings of the patients. Most common observing in these patients were leukocytopenia $(26 \%, 95 \%$ CI $17-35)$, neutrophilia $(25 \%, 95 \%$ CI $11-39)$, thrombocytopenia $(36 \%, 95 \%$ CI 30- 42) and lymphocytopenia (34\%, 95\%CI $12-57)$ by following thrombocytosis $(4 \%, 95 \%$ CI 1 - 8), increased C-reactive protein (CRP) $(56 \%, 95 \%$ CI $21-92)$, procalcitonin $(5 \%, 95 \%$ CI 1 - 8), IL-6 (42\%, 95\%CI 34 - 50), D-dimer (14\%, 95\%CI 0 - 28), and Erythrocyte sedimentation rate (ESR) (54\%, 95\%CI 28 - 79) (Fig. 7 and 8).

\section{Radiological Findings}

Regarding radiological findings, 84\% (95\%CI 79 - 88) of patients who underwent a Computed tomography (CT) scan were positive for pneumonia. The most common radiological findings in these patients were Ground-glass opacity $(50 \%, 95 \%$ CI $29-70)$, consolidation $(27 \%, 95 \%$ CI 10 -44), unilateral pneumonia $(24 \%, 95 \%$ CI 3 - 44), and bilateral pneumonia $(61 \%, 95 \%$ CI 30 - 91) (Supplementary File and Table 2).

\section{Comorbidities}

Different studies investigated the underlying diseases in patients with COVID-19. The cardiovascular disease, diabetes, and cerebrovascular disease were reported in 12, 11, and 4 original studies, respectively. In this regard, pooling of the results was 10\% (95\%CI 7 - 114), 10\% (95\% CI 7 - 14), and 2\% (95\%CI 1 - 3), respectively. Also, other underlying diseases like hypertension and chronic kidney disease were investigated in 11 and 7 studies. The general outbreak of these disorders was 18\% (95\% CI 13 - 23) and 1\% (95\%CI 1 - 2) respectively (Supplementary File and Table 2). 
medRxiv preprint doi: https://doi.org/10.1101/2020.03.26.20044057; this version posted March 30, 2020. The copyright holder for this preprint (which was not certified by peer review) is the author/funder, who has granted medRxiv a license to display the preprint in perpetuity.

All rights reserved. No reuse allowed without permission.

Other disorders prevalence was as follows: digestive tract $(5 \%, 95 \% \mathrm{CI} 1-10)$, chronic liver disease $(2 \%, 95 \%$ CI $1-4)$, endocrine disease $(6 \%, 95 \% \mathrm{CI}-1-13)$, malignancies $(2 \%, 95 \% \mathrm{CI} 1$

- 3), central nervous system $(2 \%, 95 \%$ CI $1-4)$, respiratory system $(2 \%, 95 \% 1-3)$ and immunodeficiency (0\%) (Supplementary File and Table 2).

The acute respiratory distress syndrome and acute kidney injury after infecting with COVID-19 have been investigated in 4 and 3 studies, respectively. Meta-analysis showed the prevalence of $21 \%(95 \%$ CI $6-35)$ and 2\% (95\%CI -1-5) respectively (Supplementary File and Table 2).

\section{Comorbidities and clinical findings based on severity of disease}

In this systematic review for detecting the source of heterogeneity, we analyzed the subgroups based on the severity of the disease. The results are as follows:

The prevalence of the symptoms such as sore throat, sputum production, headache, and fatigue in stable patients did not need to be admitted into intensive care unit (ICU) were 14\%, 33\%, 14\%, $44 \%$, respectively. However, these statistics for patients with severe symptoms were $14 \%, 41 \%$, $12 \%, 53 \%$. Other symptoms like diarrhea, anorexia, nausea/vomiting, and dyspnea in mild patients showed the prevalence of $9 \%, 17 \%, 6 \%$, and $24 \%$, which were $8 \%, 30 \%, 9 \%$, and $59 \%$, respectively in severe cases (Supplementary File and Table 2).

The prevalence of symptoms like abdominal pain, pharyngalgia, hemoptysis, expectoration, and fever in mild cases were $6 \%, 8 \%, 1 \%, 36 \%, 90 \%$. The same symptoms for the severe cases were $7 \%, 14 \%, 3 \%, 39 \%, 94 \%$ respectively. Furthermore, the prevalence of the symptoms of myalgia, cough, dizziness, chills, and shortness of breath were $27 \%, 68 \%, 5 \%, 11 \%$, and $19 \%$ whereas in 
medRxiv preprint doi: https://doi.org/10.1101/2020.03.26.20044057; this version posted March 30, 2020. The copyright holder for this preprint (which was not certified by peer review) is the author/funder, who has granted medRxiv a license to display the preprint in perpetuity.

All rights reserved. No reuse allowed without permission.

severe cases were 21\%,75\%,12\%, 16\%, and 39\%, respectively (Supplementary File and Table 2).

The meta-analysis showed that the prevalence of the underlying diseases like cardiovascular disease, diabetes, cerebrovascular disease and hypertension in COVID-19 patients were 4\%, 6\%, $1 \%, 14 \%$, respectively. However, in critically severe patients were $15 \%, 17 \%, 10 \%$, and $31 \%$. The prevalence of other underlying diseases like chronic liver disease and respiratory diseases were $2 \%$ and $1 \%$ whereas in severe cases, respiratory diseases prevalence is 6\% (Supplementary File and Table 2).

The prevalence of malignancies (2\%) and chronic kidney disease (1\%) mostly reported in mild patients whereas in severe cases, were $2 \%$ and $24 \%$, respectively (Supplementary File and Table 2).

\section{Discussion}

Due to the novelty of Coronavirus 2019, there is no clear picture of the clinical and paraclinical features of the disease. Moreover, the reported frequencies of these features are variable. Therefore, this systematic review and meta-analysis study was performed to evaluate the clinical and paraclinical features of the disease. In this systematic review, 20 studies including 48967 cases of COVID-19 have been studied. All the studies were conducted in China, with one exception which studies some case in South Korea along with Chinese cases.

It was difficult to diagnose this disease at the time of onset, as the general symptoms of the disease can also be seen in other respiratory diseases. A wide range of clinical, laboratory, and imaging findings have been observed in relation to this disease. Symptoms such as fever, cough, fatigue, 
and sputum were common clinical symptoms in this study, but cases such as diarrhea, chest pain and nausea were less common. As mentioned, gastrointestinal symptoms such as diarrhea and nausea are less common and symptoms such as fever and cough are more common in viral infections such as seasonal influenza, SARS and MERS. $(8,9)$. Many patients with coronavirus may be unrecognized and present in the community because, according to the results of this study, none of the clinical symptoms were definitively present in all patients. Therefore, definitive diagnosis of patients is difficult and one should expect hidden and vector-borne patients in the community. In the meta-analysis of Sun et al. which conducted on the symptoms of COVID-19 patients, the results have shown that fever, cough, and fatigue are among the most common symptoms (7).

The rate of death and the outcome of patients after hospitalization have been investigated in this meta-analysis. The results have shown more than two-thirds of the patients (69\%) who referred to the hospitals get hospitalized, and about $26 \%$ will be released after outpatient treatment. Around $3 \%$ of the patients, however, will expire. It should be noted that the real mortality rate would be higher than this statistics. In the study of Baud et al. It has been shown that the mortality of this disease is higher than that typically obtained by dividing the death rate by the total number of patients. Because at the time of infection the number of persons is much lower than the number entered into the denominator (10). Based on the present meta-analysis findings in $84 \%$ of suspected cases, CT-Scan findings were positive, indicating that a high proportion of patients can be identified by relying on CT-Scan.

On the other hand, $84 \%$ of suspected cases had high fever and cough was seen in many patients. Changes in laboratory findings are less common than radiological and clinical findings and appear to be less reliable. According to the study in the group of patients with severe conditions and 
outpatients, it was found that the symptoms associated with the disease are more common in critically ill patients at the time of diagnosis and treatment. Also, underlying diseases were more common in these patients.

The limitations of this study include:

1. All of the studies have been conducted in China

2. High methodological heterogeneity in the included studies

3. Due to the lack of information by sex and age, it was not possible to calculate the mortality and morbidity of patients in these subgroups.

\section{Conclusion}

Given the high proportion that may occur without CT-Scan findings or clinical symptoms, it is advisable to use several combination methods to better diagnose the disease, to minimize undiagnosed patients. Moreover, while there is no access to clinical and paraclinical facilities in in public places such as airports and border crossings, it is recommended to consider factors such as fever, cough, sputum and fatigue. Since the prevalence of underlying diseases is higher in patients with more severe conditions, the risk of serious illness in those with underlying diseases should be considered.

\section{Acknowledgment}

The authors would like to thank the Student Research Committee of Mazandaran University of Medical Sciences for supporting this project (Project No. 7319).

\section{Conflict of interest}

The authors have no conflicts of interest to declare. 
medRxiv preprint doi: https://doi.org/10.1101/2020.03.26.20044057; this version posted March 30, 2020. The copyright holder for this preprint (which was not certified by peer review) is the author/funder, who has granted medRxiv a license to display the preprint in perpetuity.

All rights reserved. No reuse allowed without permission. 
medRxiv preprint doi: https://doi.org/10.1101/2020.03.26.20044057; this version posted March 30, 2020. The copyright holder for this preprint (which was not certified by peer review) is the author/funder, who has granted medRxiv a license to display the preprint in perpetuity.

All rights reserved. No reuse allowed without permission.

\section{Figure Legend}

Figure 1. PRISMA flowchart for study selection process

Figure 2. Risk of bias summary (A)

Figure 3. Meta-analysis of incidence of clinical outcome of patients

Figure 4. Meta-analysis of incidence of clinical findings of patients (A)

Figure 5. Meta-analysis of incidence of clinical findings of patients (B)

Figure 6. Meta-analysis of incidence of clinical findings of patients (C)

Figure 7. Meta-analysis of incidence of laboratory findings of patients (A)

Figure 8. Meta-analysis of incidence of laboratory findings of patients (B) 


\section{Supporting Information Legend}

Supplementary figure 1 . Risk of bias summary (B)

Supplementary figure 2. Mete-analysis of incidence of Clinical findings of patients (A)

Supplementary figure 3. Mete-analysis of incidence of Clinical findings of patients (B)

Supplementary figure 4. Mete-analysis of incidence of Radiologic findings

Supplementary figure 5. Mete-analysis of prevalence of Comorbidities (A)

Supplementary figure 6. Mete-analysis of prevalence of Comorbidities (B)

Supplementary figure 7. Mete-analysis of prevalence of Clinical findings in severe patients (A)

Supplementary figure 8. Mete-analysis of prevalence of Clinical findings in severe patients (B)

Supplementary figure 9. Mete-analysis of prevalence of Clinical findings in non-severe patients (A)

Supplementary figure 10. Mete-analysis of prevalence of Clinical findings in non-severe patients (B)

Supplementary figure 11. Mete-analysis of prevalence of Comorbidities in severe patients

Supplementary figure 12. Mete-analysis of prevalence of Comorbidities in non- severe patients 


\section{References}

1. Singhal T. A Review of Coronavirus Disease-2019 (COVID-19). The Indian Journal of Pediatrics. 2020:1-6.

2. Schoeman D, Fielding BC. Coronavirus envelope protein: current knowledge. Virology journal. 2019;16(1):69.

3. Paules $\mathrm{Cl}$, Marston HD, Fauci AS. Coronavirus infections-more than just the common cold. Jama. 2020;323(8):707-8.

4. de Wit E, van Doremalen N, Falzarano D, Munster VJ. SARS and MERS: recent insights into emerging coronaviruses. Nature Reviews Microbiology. 2016;14(8):523.

5. WHO. WHO Director-General's opening remarks at the media briefing on COVID-19 - 11 March 2020: World Health Organization; 11 March 2020 [Available from: https://www.who.int/dg/speeches/detail/who-director-general-s-opening-remarks-at-the-mediabriefing-on-covid-19---11-march-2020.

6. WHO. Coronavirus disease 2019 (COVID-19) Situation Report - 57: World Health Organization; 17 March 2020 [Available from: https://www.who.int/docs/default-source/coronaviruse/situationreports/20200317-sitrep-57-covid-19.pdf?sfvrsn=a26922f2 2.

7. Sun P, Qie S, Liu Z, Ren J, Li K, Xi J. Clinical characteristics of 50466 hospitalized patients with 2019nCoV infection. Journal of Medical Virology. 2020.

8. Leung WK, To K-f, Chan PK, Chan HL, Wu AK, Lee N, et al. Enteric involvement of severe acute respiratory syndrome-associated coronavirus infection. Gastroenterology. 2003;125(4):1011-7.

9. Assiri A, McGeer A, Perl TM, Price CS, Al Rabeeah AA, Cummings DA, et al. Hospital outbreak of Middle East respiratory syndrome coronavirus. New England Journal of Medicine. 2013;369(5):407-16.

10. Baud D, Qi X, Nielsen-Saines K, Musso D, Pomar L, Favre G. Real estimates of mortality following COVID-19 infection. The Lancet Infectious Diseases. 2020. 
medRxiv preprint doi: https://doi.org/10.1101/2020.03.26.20044057; this version posted March 30, 2020. The copyright holder for this preprint (which was not certified by peer review) is the author/funder, who has granted medRxiv a license to display the preprint in perpetuity.

All rights reserved. No reuse allowed without permission.

11. Ai T, Yang Z, Hou H, Zhan C, Chen C, Lv W, et al. Correlation of Chest CT and RT-PCR Testing in Coronavirus Disease 2019 (COVID-19) in China: A Report of 1014 Cases. Radiology. 2020:200642.

12. Cai J, Xu J, Lin D, Yang Z, Xu L, Qu Z, et al. A Case Series of children with 2019 novel coronavirus infection: clinical and epidemiological features. Clinical infectious diseases : an official publication of the Infectious Diseases Society of America. 2020.

13. Chen NS, Zhou M, Dong X, Qu JM, Gong FY, Han Y, et al. Epidemiological and clinical characteristics of 99 cases of 2019 novel coronavirus pneumonia in Wuhan, China: a descriptive study. Lancet. 2020;395(10223):507-13.

14. Chen L, Liu H, Liu W, Liu J, Liu K, Shang J, et al. Analysis of clinical features of 29 patients with 2019 novel coronavirus pneumonia. Zhonghua jie he he hu xi za zhi= Zhonghua jiehe he huxi zazhi= Chinese journal of tuberculosis and respiratory diseases. 2020;43:E005.

15. Hu Z, Song C, Xu C, Jin G, Chen Y, Xu X, et al. Clinical characteristics of 24 asymptomatic infections with COVID-19 screened among close contacts in Nanjing, China. Science China Life sciences. 2020.

16. Huang CL, Wang YM, Li XW, Ren LL, Zhao JP, Hu Y, et al. Clinical features of patients infected with 2019 novel coronavirus in Wuhan, China. Lancet. 2020;395(10223):497-506.

17. Ki M, nCo VT. Epidemiologic characteristics of early cases with 2019 novel coronavirus (2019nCoV) disease in Republic of Korea. Epidemiology and health. 2020:e2020007.

18. Liu Y, Yang Y, Zhang C, Huang F, Wang F, Yuan J, et al. Clinical and biochemical indexes from 2019nCoV infected patients linked to viral loads and lung injury. Science China Life sciences. 2020;63(3):36474.

19. Liu J, Liu Y, Xiang P, Pu L, Xiong H, Li C, et al. Neutrophil-to-Lymphocyte Ratio Predicts Severe Illness Patients with 2019 Novel Coronavirus in the Early Stage. MedRxiv. 2020. 
medRxiv preprint doi: https://doi.org/10.1101/2020.03.26.20044057; this version posted March 30, 2020. The copyright holder for this preprint (which was not certified by peer review) is the author/funder, who has granted medRxiv a license to display the preprint in perpetuity.

All rights reserved. No reuse allowed without permission.

20. Qin C, Zhou L, Hu Z, Zhang S, Yang S, Tao Y, et al. Dysregulation of immune response in patients with COVID-19 in Wuhan, China. Clinical infectious diseases : an official publication of the Infectious Diseases Society of America. 2020.

21. Wu J, Liu J, Zhao X, Liu C, Wang W, Wang D, et al. Clinical Characteristics of Imported Cases of COVID-19 in Jiangsu Province: A Multicenter Descriptive Study. Clinical infectious diseases : an official publication of the Infectious Diseases Society of America. 2020.

22. Wu C, Chen X, Cai Y, Xia J, Zhou X, Xu S, et al. Risk Factors Associated With Acute Respiratory Distress Syndrome and Death in Patients With Coronavirus Disease 2019 Pneumonia in Wuhan, China. JAMA internal medicine. 2020.

23. Zhu W, Xie K, Lu H, Xu L, Zhou S, Fang S. Initial clinical features of suspected Coronavirus Disease 2019 in two emergency departments outside of Hubei, China. Journal of medical virology. 2020.

24. Xie C, Jiang L, Huang G, Pu H, Gong B, Lin H, et al. Comparison of different samples for 2019 novel coronavirus detection by nucleic acid amplification tests. International journal of infectious diseases : IJID : official publication of the International Society for Infectious Diseases. 2020.

25. Xu XW, Wu XX, Jiang XG, Xu KJ, Ying LJ, Ma CL, et al. Clinical findings in a group of patients infected with the 2019 novel coronavirus (SARS-Cov-2) outside of Wuhan, China: retrospective case series. BMJ (Clinical research ed). 2020;368:m606.

26. Yu F, Du L, Ojcius DM, Pan C, Jiang S. Measures for diagnosing and treating infections by a novel coronavirus responsible for a pneumonia outbreak originating in Wuhan, China. Microbes and infection. 2020.

27. Guan W-j, Ni Z-y, Hu Y, Liang W-h, Ou C-q, He J-x, et al. Clinical characteristics of coronavirus disease 2019 in China. New England Journal of Medicine. 2020.

28. Bernheim A, Mei X, Huang M, Yang Y, Fayad ZA, Zhang N, et al. Chest CT Findings in Coronavirus Disease-19 (COVID-19): Relationship to Duration of Infection. Radiology. 2020:200463. 
medRxiv preprint doi: https://doi.org/10.1101/2020.03.26.20044057; this version posted March 30, 2020. The copyright holder for this preprint (which was not certified by peer review) is the author/funder, who has granted medRxiv a license to display the preprint in perpetuity.

All rights reserved. No reuse allowed without permission.

29. Chung M, Bernheim A, Mei X, Zhang N, Huang M, Zeng X, et al. CT imaging features of 2019 novel coronavirus (2019-nCoV). Radiology. 2020:200230.

30. Chang D, Lin M, Wei L, Xie L, Zhu G, Cruz CSD, et al. Epidemiologic and clinical characteristics of novel coronavirus infections involving 13 patients outside Wuhan, China. Jama. 2020.

31. Cheng Z, Lu Y, Cao Q, Qin L, Pan Z, Yan F, et al. Clinical Features and Chest CT Manifestations of Coronavirus Disease 2019 (COVID-19) in a Single-Center Study in Shanghai, China. AJR American journal of roentgenology. 2020:1-6.

32. Pan F, Ye T, Sun P, Gui S, Liang B, Li L, et al. Time course of lung changes on chest CT during recovery from 2019 novel coronavirus (COVID-19) pneumonia. Radiology. 2020:200370.

33. Pan $Y$, Guan $H$, Zhou $S$, Wang $Y$, Li $Q$, Zhu $T$, et al. Initial $C T$ findings and temporal changes in patients with the novel coronavirus pneumonia (2019-nCoV): a study of 63 patients in Wuhan, China. European radiology. 2020:1-4.

34. Yang $\mathrm{X}, \mathrm{Yu} \mathrm{Y,} \mathrm{Xu} \mathrm{J,} \mathrm{Shu} \mathrm{H,} \mathrm{Liu} \mathrm{H,} \mathrm{Wu} \mathrm{Y,} \mathrm{et} \mathrm{al.} \mathrm{Clinical} \mathrm{course} \mathrm{and} \mathrm{outcomes} \mathrm{of} \mathrm{critically} \mathrm{ill} \mathrm{patients}$ with SARS-CoV-2 pneumonia in Wuhan, China: a single-centered, retrospective, observational study. Lancet Respir Med. 2020.

35. Novel CPERE. The epidemiological characteristics of an outbreak of 2019 novel coronavirus diseases (COVID-19) in China. Zhonghua liu xing bing xue za zhi= Zhonghua liuxingbingxue zazhi. 2020;41(2):145.

36. Zhang M, Wang X, Chen Y, Zhao K, Cai Y, An C, et al. Clinical features of 2019 novel coronavirus pneumonia in the early stage from a fever clinic in Beijing. Zhonghua jie he he hu xi za zhi= Zhonghua jiehe he huxi zazhi= Chinese journal of tuberculosis and respiratory diseases. 2020;43(3):215.

37. Han R, Huang L, Jiang H, Dong J, Peng H, Zhang D. Early Clinical and CT Manifestations of Coronavirus Disease 2019 (COVID-19) Pneumonia. AJR American journal of roentgenology. 2020:1-6. 
medRxiv preprint doi: https://doi.org/10.1101/2020.03.26.20044057; this version posted March 30, 2020. The copyright holder for this preprint (which was not certified by peer review) is the author/funder, who has granted medRxiv a license to display the preprint in perpetuity. All rights reserved. No reuse allowed without permission.

38. Feng K, Yun Y, Wang X, Yang G, Zheng Y, Lin C, et al. Analysis of CT features of 15 Children with 2019 novel coronavirus infection. Zhonghua er ke za zhi= Chinese journal of pediatrics. 2020;58:E007.

39. Wang D, Hu B, Hu C, Zhu F, Liu X, Zhang J, et al. Clinical characteristics of 138 hospitalized patients with 2019 novel coronavirus-infected pneumonia in Wuhan, China. Jama. 2020.

40. Wang X, Yuan J, Zheng Y, Chen J, Bao Y, Wang Y, et al. Clinical and epidemiological characteristics of 34 children with 2019 novel coronavirus infection in Shenzhen. Zhonghua er ke za zhi= Chinese journal of pediatrics. 2020;58:E008.

41. Wang Z, Yang B, Li Q, Wen L, Zhang R. Clinical Features of 69 Cases with Coronavirus Disease 2019 in Wuhan, China. Clinical infectious diseases : an official publication of the Infectious Diseases Society of America. 2020.

42. Li J, Li S, Cai Y, Liu Q, Li X, Zeng Z, et al. Epidemiological and Clinical Characteristics of 17 Hospitalized Patients with 2019 Novel Coronavirus Infections Outside Wuhan, China. medRxiv. 2020. 


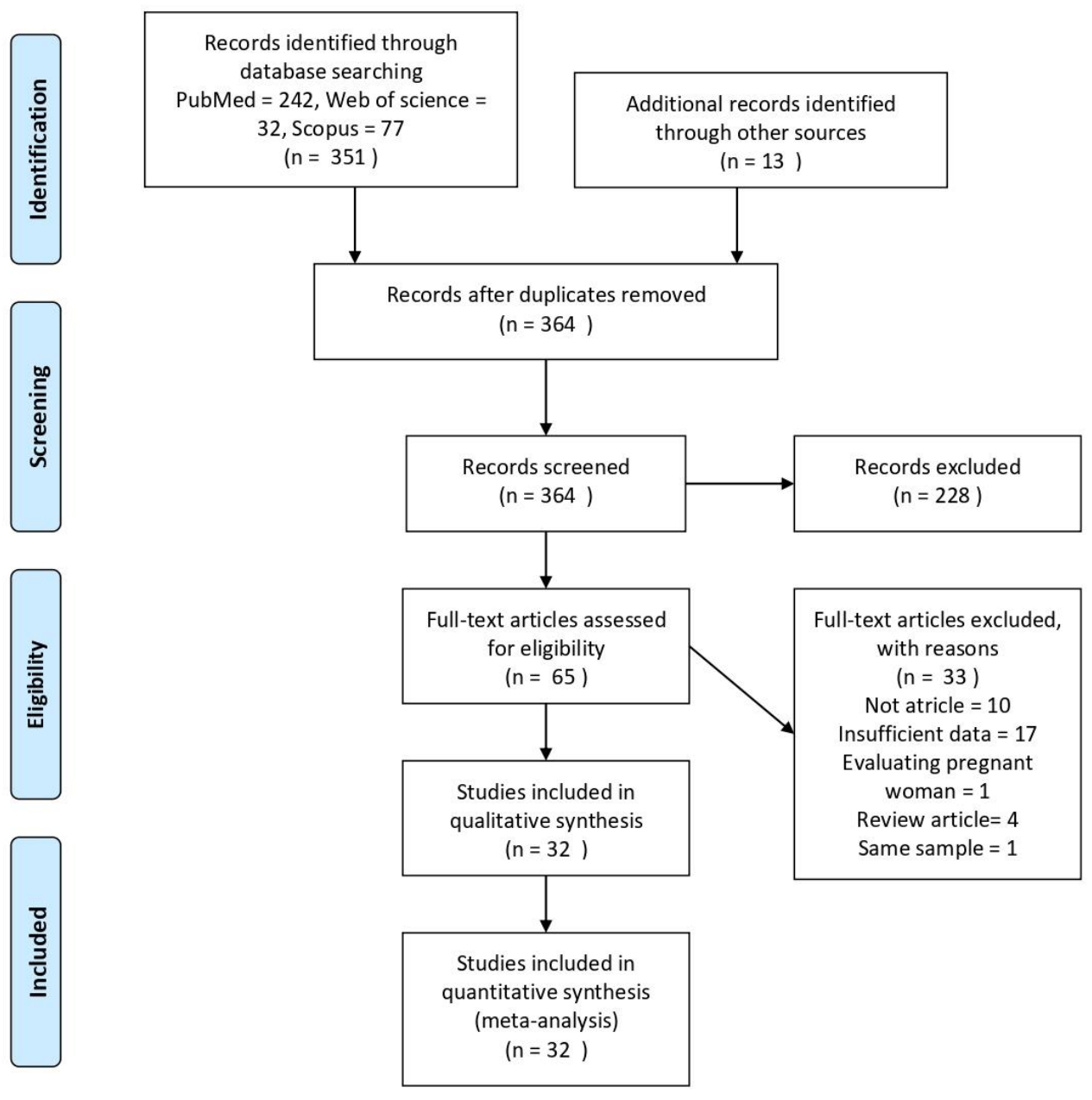

Figure 1. PRISMA flowchart for study selection process 
medRxiv preprint doi: https://doi.org/10.1101/2020.03.26.20044057; this version posted March 30, 2020. The copyright holder for this preprint (which was not certified by peer review) is the author/funder, who has granted medRxiv a license to display the preprint in perpetuity.

All rights reserved. No reuse allowed without permission.

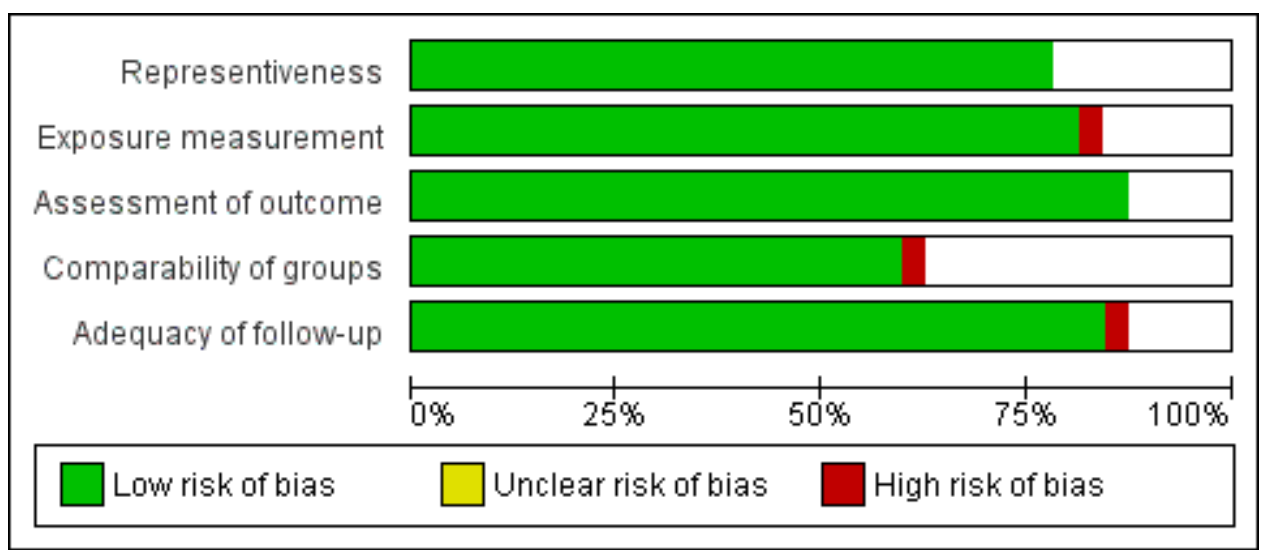

Figure 2. Risk of bias summary (A) 
medRxiv preprint doi: https://doi.org/10.1101/2020.03.26.20044057; this version posted March 30, 2020. The copyright holder for this preprint (which was not certified by peer review) is the author/funder, who has granted medRxiv a license to display the preprint in perpetuity. All rights reserved. No reuse allowed without permission.

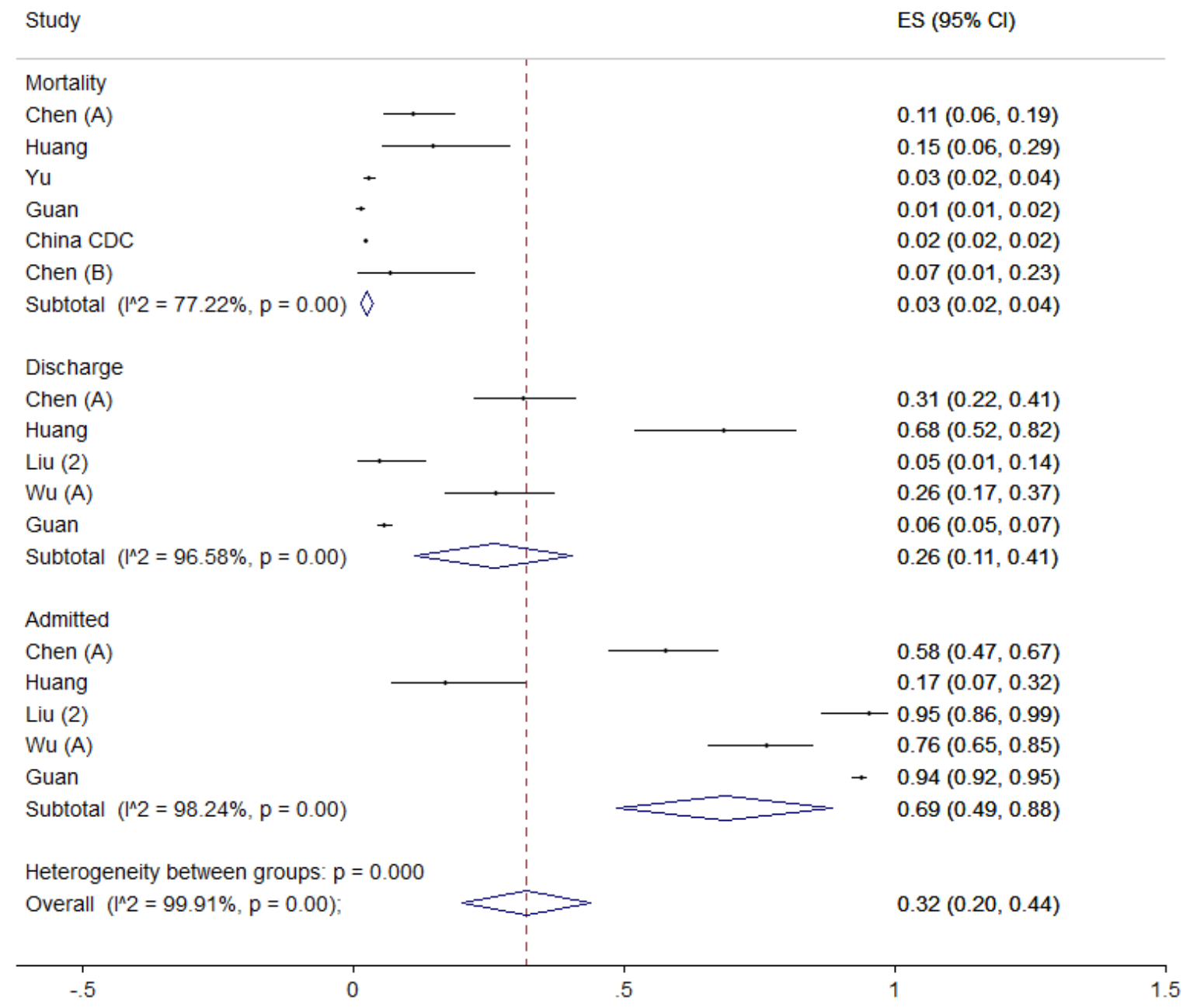

Figure 3. Meta-analysis of incidence of clinical outcome of patients 
medRxiv preprint doi: https://doi.org/10.1101/2020.03.26.20044057; this version posted March 30, 2020. The copyright holder for this preprint (which was not certified by peer review) is the author/funder, who has granted medRxiv a license to display the preprint in perpetuity.

All rights reserved. No reuse allowed without permission.

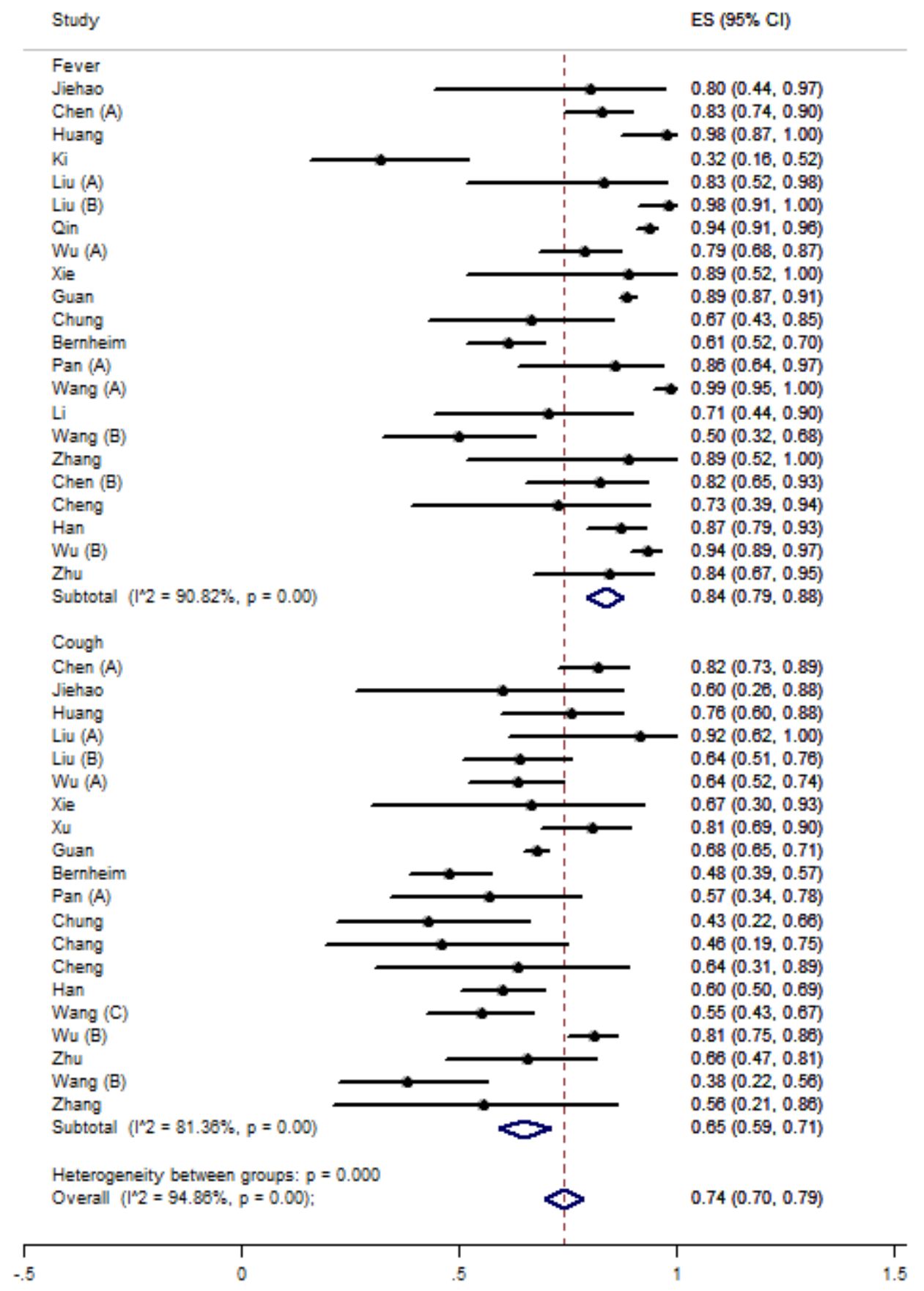

Figure 4. Meta-analysis of incidence of clinical findings of patients $(A)$ 
medRxiv preprint doi: https://doi.org/10.1101/2020.03.26.20044057; this version posted March 30, 2020. The copyright holder for this preprint (which was not certified by peer review) is the author/funder, who has granted medRxiv a license to display the preprint in perpetuity. All rights reserved. No reuse allowed without permission.

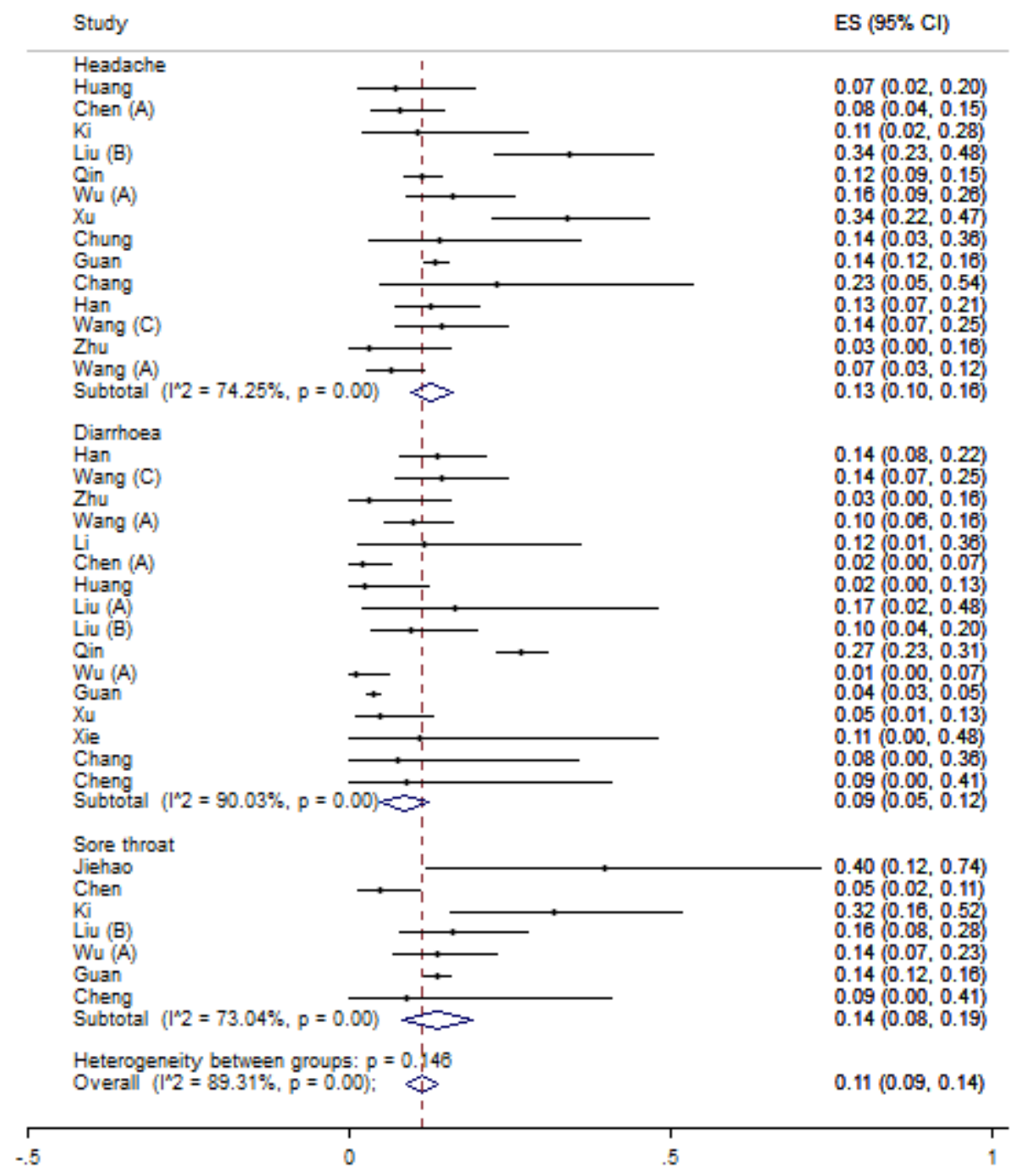

Figure 5. Meta-analysis of incidence of clinical findings of patients (B) 
medRxiv preprint doi: https://doi.org/10.1101/2020.03.26.20044057; this version posted March 30, 2020. The copyright holder for this preprint (which was not certified by peer review) is the author/funder, who has granted medRxiv a license to display the preprint in perpetuity. All rights reserved. No reuse allowed without permission.

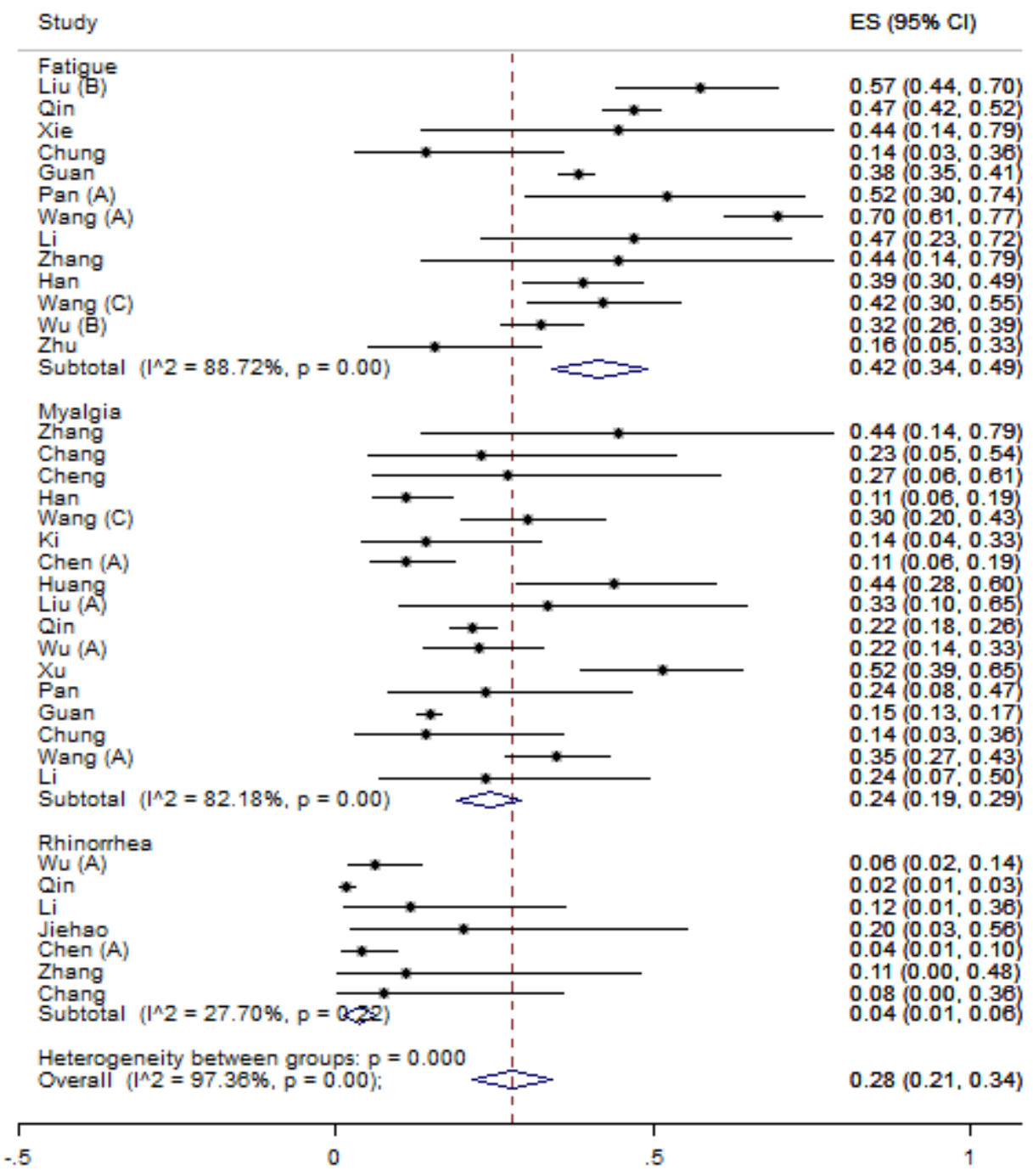

Figure 6. Meta-analysis of incidence of clinical findings of patients $(C)$ 
medRxiv preprint doi: https://doi.org/10.1101/2020.03.26.20044057; this version posted March 30, 2020. The copyright holder for this preprint (which was not certified by peer review) is the author/funder, who has granted medRxiv a license to display the preprint in perpetuity.

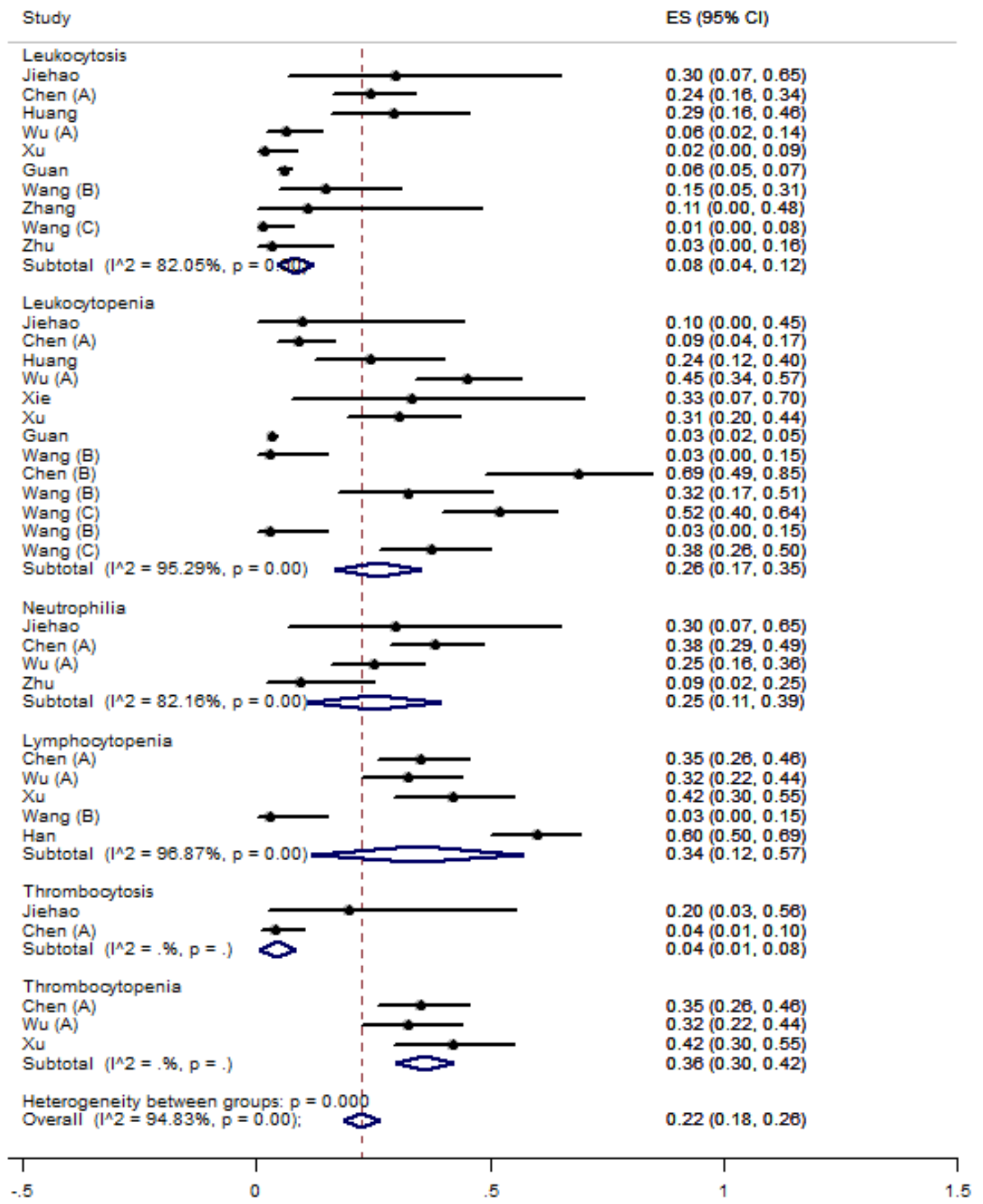

Figure 7. Meta-analysis of incidence of laboratory findings of patients (A) 
medRxiv preprint doi: https://doi.org/10.1101/2020.03.26.20044057; this version posted March 30, 2020. The copyright holder for this preprint (which was not certified by peer review) is the author/funder, who has granted medRxiv a license to display the preprint in perpetuity. All rights reserved. No reuse allowed without permission.

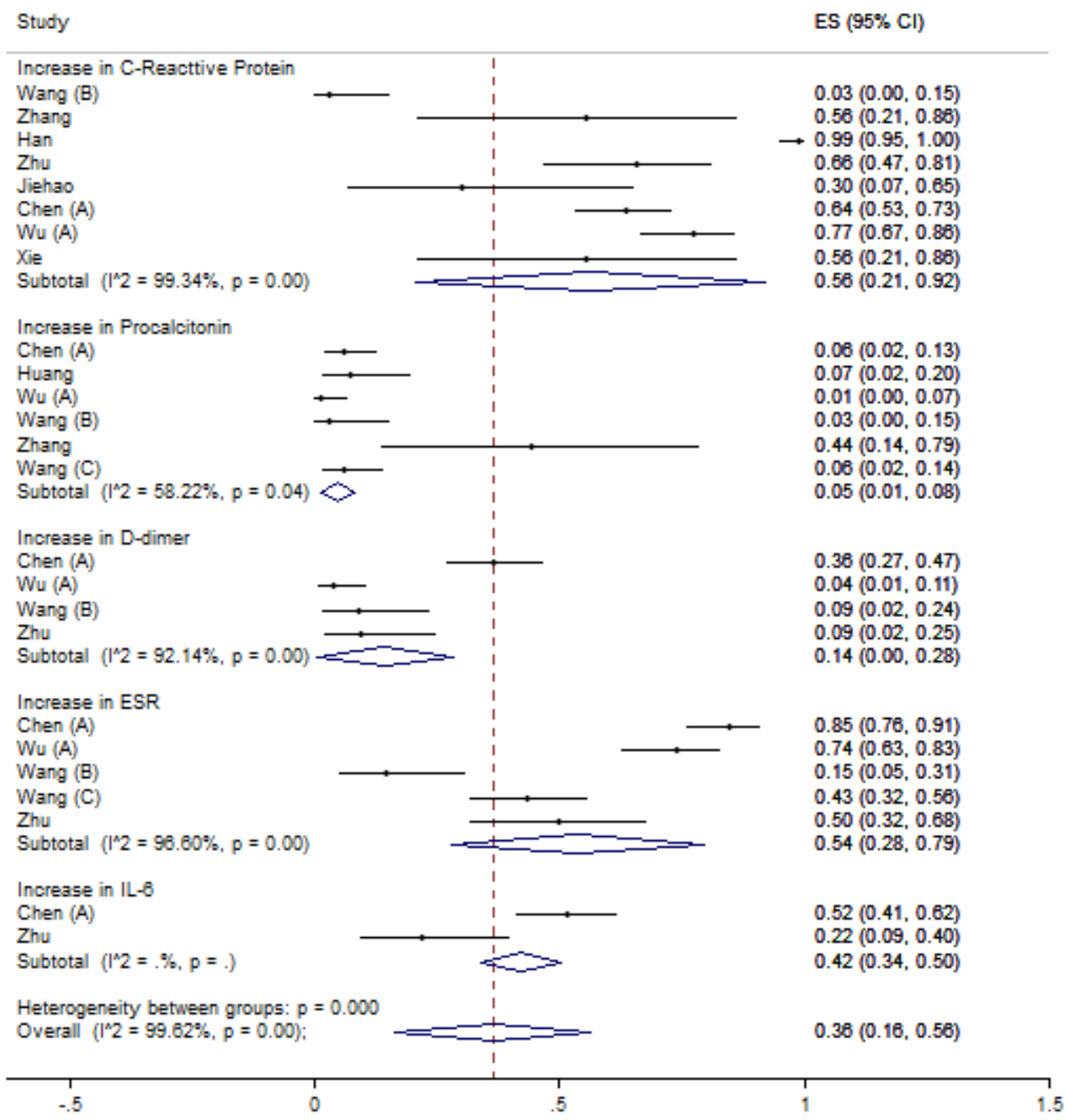

Figure 8. Meta-analysis of incidence of laboratory findings of patients (B) 
Table 1. Characteristics of studies entered into the meta-analysis

\begin{tabular}{|c|c|c|c|c|c|c|c|c|c|c|c|}
\hline Author & Country & $\begin{array}{c}\text { Type } \\
\text { of } \\
\text { study }\end{array}$ & $\begin{array}{c}\text { No. of } \\
\text { Patients }\end{array}$ & $\begin{array}{l}\text { Mean } \\
\text { Age } \\
\text { (SD) }\end{array}$ & $\begin{array}{l}\text { Clinical } \\
\text { findings }\end{array}$ & $\begin{array}{c}\text { WBC count } \\
\left(10^{9} / \mathrm{L}\right)\end{array}$ & $\begin{array}{c}\text { Neutrophil } \\
\text { count } \\
\left(10^{9} / \mathrm{L}\right)\end{array}$ & $\begin{array}{l}\text { Lymphocyte } \\
\text { count }\left(10^{9} / \mathrm{L}\right)\end{array}$ & $\begin{array}{l}\text { Platelet count } \\
\qquad\left(10^{9} / \mathrm{L}\right)\end{array}$ & Comorbidities & $\begin{array}{l}\text { Q/A } \\
\text { score }\end{array}$ \\
\hline $\mathrm{Ai}(11)$ & China & $\mathrm{R}$ & $\begin{array}{c}1014 \\
(467 / 547)\end{array}$ & $51(15)$ & - & - & - & - & - & - & 3 \\
\hline Jiehao (12) & China & $\mathrm{CS}$ & $10(4 / 6)$ & - & $\begin{array}{c}\text { Fever, Cough, } \\
\text { Sneezing, Nasal } \\
\text { congestion, } \\
\text { Rhinorrhea, Sore throat }\end{array}$ & - & - & - & - & - & 3 \\
\hline $\begin{array}{l}\text { Chen }(\mathrm{A}) \\
(13)\end{array}$ & China & $\mathrm{R}$ & $99(67 / 32)$ & $\begin{array}{c}55.5 \\
(13.1)\end{array}$ & $\begin{array}{c}\text { Fever, Myalgia, Cough, } \\
\text { Rhinorrhea, Sore } \\
\text { throat, Shortness of } \\
\text { breath, Confusion, } \\
\text { Headache, Chest pain, } \\
\text { Diarrhea, N/V }\end{array}$ & - & - & - & - & $\begin{array}{c}\text { CVD, DD, ESD, } \\
\text { MD, CNSD, } \\
\text { RSD, }\end{array}$ & 4 \\
\hline
\end{tabular}




\begin{tabular}{|c|c|c|c|c|c|c|c|c|c|c|c|}
\hline $\begin{array}{l}\text { Chen (B) } \\
\text { (14) }\end{array}$ & China & $\mathrm{R}$ & 29 & - & Fever & - & - & - & - & - & 3 \\
\hline $\mathrm{Hu}(15)$ & China & $\mathrm{CS}$ & 24 & - & - & - & - & - & - & - & 3 \\
\hline Huang (16) & China & $\mathrm{R}$ & $41(30 / 11)$ & 49 & $\begin{array}{l}\text { Fever, Myalgia, Cough, } \\
\text { Sputum production, } \\
\text { Dyspnea, Headache, } \\
\text { Diarrhea }\end{array}$ & $6.2(4.1-10.5)$ & $5(33-8.9)$ & $0.8(0.6-1.1)$ & - & $\begin{array}{c}\text { CVD, DM, } \\
\text { HTN, DD, MD, } \\
\text { RSD, }\end{array}$ & 5 \\
\hline Ki (17) & $\begin{array}{c}\text { Korea/Chi } \\
\text { na }\end{array}$ & $\mathrm{CS}$ & $28(15 / 13)$ & - & $\begin{array}{c}\text { Fever, Myalgia, } \\
\text { Sneezing, Sputum } \\
\text { production, Chills, } \\
\text { Sore throat, Headache }\end{array}$ & - & - & - & - & - & 4 \\
\hline $\begin{array}{l}\text { Liu (A) } \\
(18)\end{array}$ & China & CS & $12(8 / 4)$ & - & $\begin{array}{l}\text { Fever, Myalgia, Cough, } \\
\text { Chills, Diarrhea, N/V }\end{array}$ & - & - & - & - & $\begin{array}{c}\text { CVD, DM, } \\
\text { HTN, RSD, } \\
\text { CKD }\end{array}$ & 4 \\
\hline $\begin{array}{l}\text { Liu (B) } \\
\text { (19) }\end{array}$ & China & $\mathrm{CS}$ & $61(31 / 30)$ & $40^{*}$ & $\begin{array}{l}\text { Fever, Cough, Sputum } \\
\text { production, Chills, } \\
\text { Sore throat, Shortness } \\
\text { of breath, Dyspnea, } \\
\text { Headache, Fatigue, }\end{array}$ & $4.3(3.5-5.1)$ & $2.5(2.1-3.5)$ & - & $164(135.0-219.5)$ & $\begin{array}{l}\text { CVD, DM, } \\
\text { HTN, RSD, }\end{array}$ & 4 \\
\hline
\end{tabular}




\begin{tabular}{|c|c|c|c|c|c|c|c|c|c|c|c|}
\hline & & & & & $\begin{array}{c}\text { Chest pain, Diarrhea, } \\
\text { Anorexia, N/V }\end{array}$ & & & & & & \\
\hline Qin (20) & China & $\mathrm{CS}$ & $452(235 / 217)$ & $58 *$ & $\begin{array}{c}\text { Abdominal pain, } \\
\text { Pharyngalgia, } \\
\text { Hemoptysis, } \\
\text { Expectoration, Fever, } \\
\text { Myalgia, Sneezing, } \\
\text { Dizziness, Rhinorrhea, } \\
\text { Shortness of breath, } \\
\text { Confusion, Headache, } \\
\text { Fatigue, Diarrhea, } \\
\text { Anorexia, N/V }\end{array}$ & 5.3(3.9-7.5) & $3.9(2.6-5.8)$ & $0.9(0.6-1.2)$ & 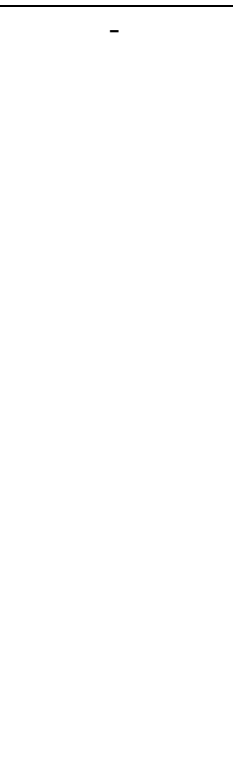 & $\begin{array}{c}\text { CVD, DM, CD, } \\
\text { HTN, CLD, } \\
\text { MD, RSD, CKD }\end{array}$ & 4 \\
\hline $\begin{array}{l}\text { Wu (A) } \\
(21)\end{array}$ & China & $\mathrm{R}$ & $80(39 / 41)$ & $\begin{array}{c}46.1 \\
(15.42)\end{array}$ & $\begin{array}{c}\text { Fever, Myalgia, Cough, } \\
\text { Rhinorrhea, Sore } \\
\text { throat, Shortness of } \\
\text { breath, Headache, } \\
\text { Diarrhea, N/V }\end{array}$ & $4.1(3.2-5.7)$ & $4.3(2.3-5.9)$ & $0.6(0.4-1.0)$ & 155 (116-188) & $\begin{array}{c}\text { CVD, DD, } \\
\text { CLD, ESD, } \\
\text { MD, } \\
\text { CNSD,RSD, } \\
\text { CKD }\end{array}$ & 5 \\
\hline $\begin{array}{l}\text { Wu (B) } \\
(22)\end{array}$ & China & $\mathrm{R}$ & $201(128 / 73)$ & $51^{*}$ & $\begin{array}{l}\text { Fever, Cough, } \\
\text { Dyspnea, Fatigue }\end{array}$ & $\begin{array}{c}5.94(3.80- \\
9.08)\end{array}$ & $\begin{array}{c}4.47(2.32- \\
7.70)\end{array}$ & $\begin{array}{c}0.91(0.60- \\
1.29)\end{array}$ & & $\begin{array}{c}\text { CVD, DM, } \\
\text { HTN, CLD, } \\
\text { MD, RSD, ESD }\end{array}$ & 3 \\
\hline
\end{tabular}




\begin{tabular}{|c|c|c|c|c|c|c|c|c|c|c|c|}
\hline Zhu (23) & China & $\mathrm{R}$ & $32(15 / 16)$ & $46^{*}$ & $\begin{array}{c}\text { Expectoration, Fever, } \\
\text { Cough, Headache, } \\
\text { Fatigue, Diarrhea }\end{array}$ & - & - & - & $157.2(83-284)$ & $\begin{array}{c}\text { CVD, DM, } \\
\text { HTN, CLD, } \\
\text { MD, ESD, CD, }\end{array}$ & 4 \\
\hline Xie (24) & China & & $9(4 / 5)$ & - & $\begin{array}{c}\text { Fever, Cough, Fatigue, } \\
\text { Diarrhea }\end{array}$ & - & - & - & - & - & 4 \\
\hline $\mathrm{Xu} \mathrm{(25)}$ & China & CS & $62(36 / 27)$ & & $\begin{array}{c}\text { Hemoptysis, } \\
\text { Expectoration, } \\
\text { Myalgia, Cough, } \\
\text { Headache, Chest pain, } \\
\text { Diarrhea }\end{array}$ & $4.7(3.5-5.8)$ & $2.0(2.0-3.7)$ & $1.0(0.8-1.5)$ & $176(135.8-215.5)$ & $\begin{array}{c}\text { CVD, DM, } \\
\text { HTN, CLD, } \\
\text { RSD, }\end{array}$ & 5 \\
\hline $\mathrm{Yu}(26)$ & China & & 887 & - & - & - & - & - & - & - & 3 \\
\hline Guan (27) & China & $\mathrm{R}$ & $\begin{array}{c}1099 \\
(640 / 459)\end{array}$ & $47 *$ & $\begin{array}{c}\text { Hemoptysis, Fever, } \\
\text { Myalgia, Cough, } \\
\text { Sputum production, } \\
\text { Chills, Nasal } \\
\text { congestion, Sore throat, } \\
\text { Shortness of breath, } \\
\text { Headache, Fatigue, } \\
\text { Diarrhea, N/V }\end{array}$ & $4.7(3.5-6)$ & - & - & $168(132-207)$ & $\begin{array}{l}\text { CVD, DM, CD, } \\
\text { HTN, MD, } \\
\text { RSD, ID, CKD, }\end{array}$ & 5 \\
\hline
\end{tabular}




\begin{tabular}{|c|c|c|c|c|c|c|c|c|c|c|c|}
\hline Yang (34) & China & $\mathrm{R}$ & $52(35 / 17)$ & $\begin{array}{l}59.7 \\
(13.3)\end{array}$ & $\begin{array}{c}\text { Fever, Myalgia, Cough, } \\
\text { Rhinorrhea, Headache, } \\
\text { Chest pain, N/V }\end{array}$ & - & - & - & - & $\begin{array}{l}\mathrm{DM}, \mathrm{CD}, \mathrm{MD}, \\
\mathrm{CNSD}, \mathrm{RSD}, \\
\text { CKD }\end{array}$ & 3 \\
\hline $\begin{array}{l}\text { China } \\
\text { CDC } \\
(35)\end{array}$ & China & CS & $\begin{array}{c}44672(22981 / \\
21691)\end{array}$ & - & . & - & - & - & - & - & 5 \\
\hline Zhang (36) & China & CS & $9(5 / 4)$ & $36^{*}$ & $\begin{array}{c}\text { Pharyngalgia, Myalgia, } \\
\text { Fever, Cough, , Nasal } \\
\text { congestion, } \\
\text { Rhinorrhea, Fatigue }\end{array}$ & - & - & - & - & - & 4 \\
\hline Han (37) & China & CS & $108(38 / 70)$ & $45^{*}$ & $\begin{array}{c}\text { Pharyngalgia, Fever, } \\
\text { Myalgia, Cough, } \\
\text { Headache, Chest pain, } \\
\text { Fatigue, Diarrhea }\end{array}$ & & & & 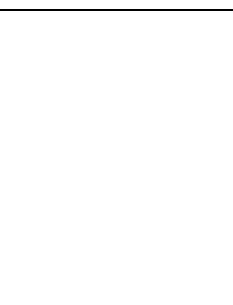 & 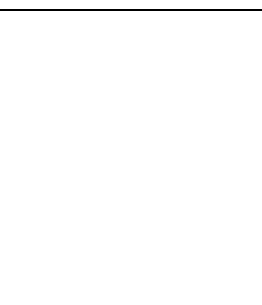 & 3 \\
\hline Feng (38) & China & CS & $15(5 / 10)$ & - & - & - & - & - & - & - & 3 \\
\hline $\begin{array}{l}\text { Wang (A) } \\
(39)\end{array}$ & China & CS & $138(75 / 63)$ & $56^{*}$ & $\begin{array}{c}\text { Abdominal pain, } \\
\text { Pharyngalgia, } \\
\text { Expectoration, Fever, } \\
\text { Myalgia, Cough, } \\
\text { Dizziness, Dyspnea, }\end{array}$ & $4.5(3.3-6.2)$ & $3.0(2.0-4.9)$ & $0.8(0.6-1.1)$ & $163(123-191)$ & $\begin{array}{l}\text { CVD, DM, CD, } \\
\text { HTN, CLD,MD, } \\
\text { RSD, ID, CKD, }\end{array}$ & 5 \\
\hline
\end{tabular}




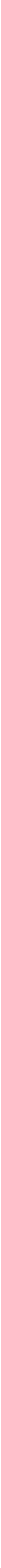


medRxiv preprint doi: https://doi.org/10.1101/2020.03.26.20044057; this version posted March 30, 2020. The copyright holder for this preprint (which was not certified by peer review) is the author/funder, who has granted medRxiv a license to display the preprint in perpetuity.

All rights reserved. No reuse allowed without permission.

\section{Table 2. Summarized Pooled values of Considered findings}

All Patients

\begin{tabular}{lllll}
\hline N. of & I- & ES\% (95\%CI) & N. of & I-
\end{tabular}

study squared
Severe $\mathrm{ES} \%(95 \% \mathrm{CI})$

study squared
Non-severe

N. of I-

$\mathrm{ES} \%(95 \% \mathrm{CI})$

study squared

\section{Clinical outcomes}

Discharge

$5 \quad 96.58 \quad 26(11-41)$

Death

$6 \quad 77.22 \quad 3(2-4)$

Hospitalization

$5 \quad 98.24 \quad 69(49-88)$

\section{Clinical findings}

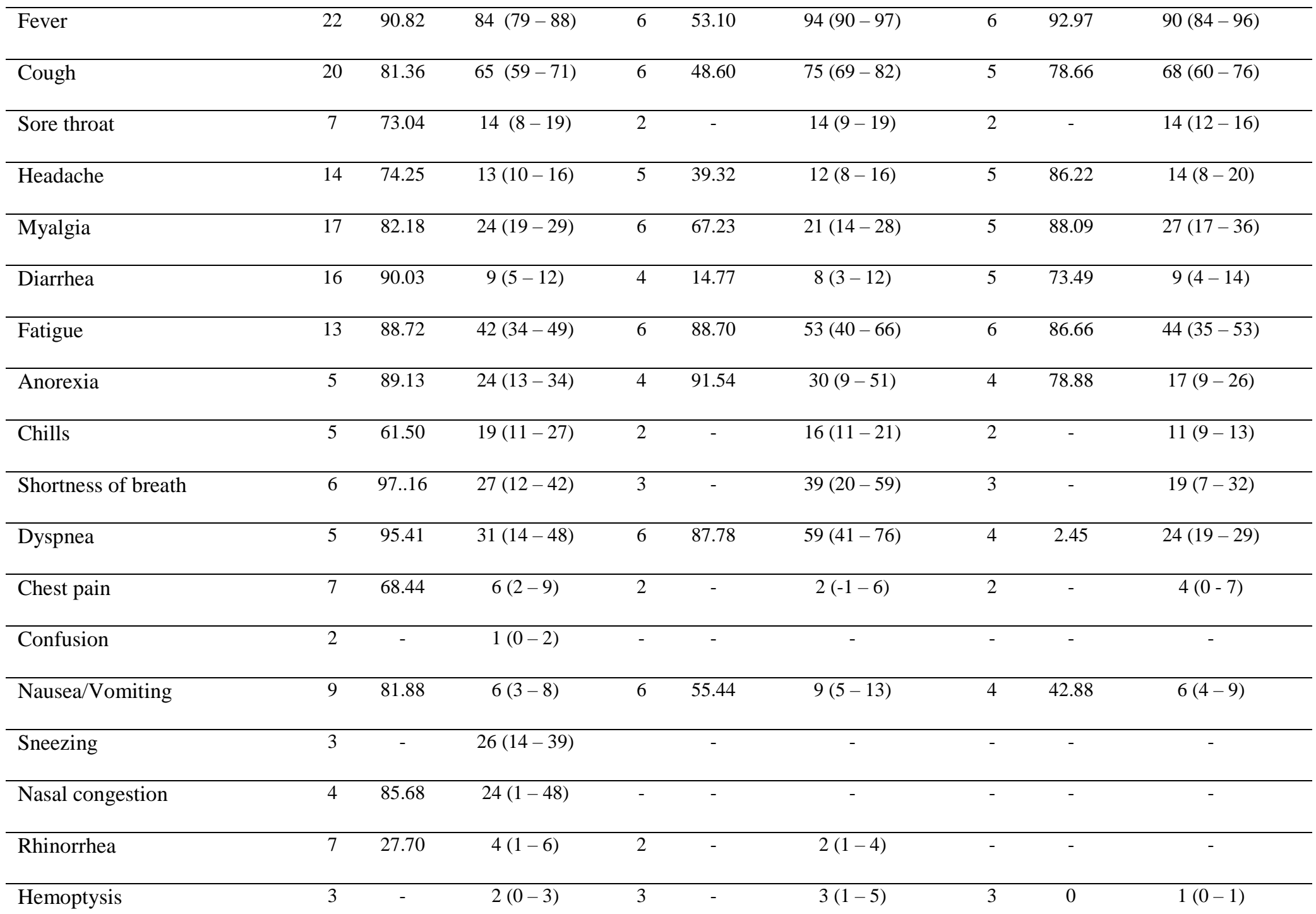




\begin{tabular}{|c|c|c|c|c|c|c|c|c|c|}
\hline Expectoration & 4 & 85.52 & $39(27-51)$ & 2 & - & $39(34-45)$ & 2 & 0 & $36(30-41)$ \\
\hline Abdominal pain & 2 & - & $4(2-5)$ & 2 & 0 & $7(4-10)$ & 2 & - & $6(3-8)$ \\
\hline Pharyngalgia & 5 & 83.00 & $12(5-19)$ & 3 & - & $14(-2-29)$ & 3 & - & $8(5-12)$ \\
\hline Dizziness & 4 & 00.00 & $8(6-10)$ & 3 & - & $12(5-18)$ & 3 & - & $5(3-8)$ \\
\hline Sputum production & 8 & 78.20 & $27(20-35)$ & 4 & 53.39 & $41(27-54)$ & 4 & 0 & $33(30-36)$ \\
\hline Laboratory findings & - & - & - & - & - & - & - & - & - \\
\hline Leukocytosis & 10 & 82.05 & $8(4-12)$ & & & & & & \\
\hline Leukocytopenia & 13 & 95.29 & $26(17-35)$ & - & - & - & - & - & - \\
\hline Lymphocytopenia & 5 & 96.87 & $34(12-57)$ & - & - & - & - & - & - \\
\hline Neutrophilia & 4 & 82.16 & $25(11-39)$ & - & - & - & - & - & - \\
\hline Thrombocytopenia & 3 & - & $36(30-42)$ & - & - & - & - & - & - \\
\hline Thrombocytosis & 2 & - & $4(1-8)$ & - & - & - & - & - & - \\
\hline Increase in C-Reactive Protein & 8 & 99.34 & $56(21-92)$ & - & - & - & - & - & - \\
\hline Increase in Procalcitonin & 6 & 58.22 & $5(1-8)$ & - & - & - & - & - & - \\
\hline Increase in D-dimer & 4 & 92.14 & $14(0-28)$ & - & - & - & - & - & - \\
\hline Increase in ESR & 5 & 96.60 & $54(28-79)$ & - & - & - & - & - & - \\
\hline Increase in IL-6 & 2 & - & $42(34-50)$ & & & & & & \\
\hline Radiologic findings & 5 & 74.69 & $84(79-88)$ & - & - & - & - & - & - \\
\hline Ground-glass opacity & 11 & 99.52 & $50(29-70)$ & - & - & - & - & - & - \\
\hline Consolidation & 7 & 97.29 & $27(10-44)$ & - & - & - & - & - & - \\
\hline Unilateral pneumonia & 5 & 98.58 & $24(3-44)$ & - & - & - & - & - & - \\
\hline Bilateral pneumonia & 9 & 99.77 & $61(30-91)$ & - & - & - & - & - & - \\
\hline Comorbidities & - & - & - & - & - & - & - & - & - \\
\hline Cardiovascular disease & 12 & 92.35 & $10(7-114)$ & 5 & 70.43 & $15(5-26)$ & 5 & 66.11 & $4(1-6)$ \\
\hline Cerebrovascular disease & 4 & 44.55 & $2(1-3)$ & 3 & - & $10(0-20)$ & 3 & - & $1(1-2)$ \\
\hline Diabetes & 11 & 79.17 & $10(7-14)$ & 7 & 4.03 & $17(14-21)$ & 7 & 67.85 & $6(4-9)$ \\
\hline Hypertension & 11 & 84.54 & $18(13-23)$ & 5 & 76.93 & $31(19-44)$ & 6 & 46.20 & $14(11-18)$ \\
\hline
\end{tabular}


medRxiv preprint doi: https://doi.org/10.1101/2020.03.26.20044057; this version posted March 30, 2020. The copyright holder for this preprint (which was not certified by peer review) is the author/funder, who has granted medRxiv a license to display the preprint in perpetuity.

All rights reserved. No reuse allowed without permission.

\begin{tabular}{|c|c|c|c|c|c|c|c|c|c|}
\hline Chronic kidney disease & 7 & 30.24 & $1(1-2)$ & 3 & - & $24(-3-51)$ & 3 & - & $1(0-2)$ \\
\hline Digestive system disease & 3 & - & $5(1-10)$ & - & - & - & - & - & - \\
\hline Chronic liver disease & 8 & 33.07 & $2(1-4)$ & - & - & - & 3 & - & $2(1-4)$ \\
\hline Endocrine system disease & 3 & - & $6(-1-13)$ & - & - & - & - & - & - \\
\hline Malignancy & 9 & 60.45 & $2(1-3)$ & 3 & - & $2(0-4)$ & 3 & - & $2(0-3)$ \\
\hline CNS disorder & 4 & 5.30 & $2(1-4)$ & - & - & - & - & - & - \\
\hline Respiratory system disease & 13 & 41.45 & $2(1-3)$ & 5 & 21.15 & $6(2-10)$ & 5 & 0 & $1(0-1)$ \\
\hline Immunodeficiency & 2 & - & 0 & - & - & - & - & - & - \\
\hline Complications & - & - & - & - & - & - & - & - & - \\
\hline Acute kidney injury & 3 & - & $2(-1-5)$ & - & - & - & - & - & - \\
\hline Acute respiratory distress & 4 & 91.70 & $21(6-35)$ & - & - & - & - & - & - \\
\hline syndrome & & & & & & & & & \\
\hline
\end{tabular}

